UDC 005.21:658.81

DOI: https://doi.org/10.32782/2224-6282/158-11

\author{
Fayvishenko Diana \\ PhD (Economic Sciences), Associate Professor \\ Department of Journalism and Advertising, \\ Kyiv National University of Trade and Economics \\ ORCID: https://orcid.org/0000-0001-7880-9801 \\ Romanchenko Tatyana \\ Postgraduate Student, Department of Marketing, \\ Kyiv National University of Trade and Economics \\ ORCID: https://orcid.org/0000-0002-2679-3454
} Файвішенко Д. С.
кандидат економічних наук, доцент,
Кицевськи кафедри журналістики та реклами,
доци національний торговельно-економічний університет

Романченко Т. В.

аспірантка кафедри маркетингу, Київський національний торговельно-економічний університет

\title{
STRATEGIC DIRECTIONS OF SALES MANAGEMENT
}

In the article is considered the main directions of the formation of a marketing sales strategy in the field of retail trade are considered, the main management decisions in this area are analyzed, the forecast paths of the evolution of retail chains and the place of the sales strategy as a functional component in the general system of strategies for the development of retail chains are identified, the main directions of the development of sales strategies in specific industries are presented, the relevance of the omnichannel approach to strategic sales management is substantiated adaptation and use of new technologies and tools for sales channels. Prospects for further exploration are the development of a model for strategic sales management in a crisis and the development of predictive ways of evolution of trade networks.

Keywords: strategic directions, marketing sales strategy, strategic management, trade, retail, consumer journey.

JEL classification: M11, M19, M31

\section{СТРАТЕГІЧНІ НАПРЯМИ УПРАВЛІННЯ ЗБУТОМ}

В умовах імпульсного розвитку економіки України, посиленої взаємодї учасників і складових ринку, зростання активності в мережі Інтернет та постійної зміни потреб споживчої аудиторії, ключовим питанням екстенсивного розвитку вітчизняних підприємств торгівлі є наявність орієнтирів і прогнозованих шляхів еволюиії торгових мереж, впровадження оптимальних маркетингових стратегій збуту, пошук та формування лояльності до споживача, посилення та займання лідируючи позицій на ринку, розширення каналів збуту з використанням інноваџійних інструментів до просування продукту при відкритій взаємодї̈ на всіх рівнях. Аналіз останніх досліджень і публікаиій показав, щчо прочес вибору й прийняття управлінських рішень розробки та впровадження ефективних заходів щодо стратегічних напрямів управління збутом для здійснення результативної маркетингової збутової стратегії підприємств торгівлі в умовах швидкоплинності та адаптації ринкової економіки до нових умов, вплив глобальних трендів залишається недостатньо вивченими та актуальними і сьогодні. У статті на основні аналізу світових тендениій розвитку маркетингових стратегій збуту, використання загальнонаукових та спеціальних методів спостереження, принципів узагальнення, порівняльного та структурного аналізу, систематизовано статистичні дані, проаналізовано основні аспекти формування маркетингової збутової стратегії, виокремлено стратегічні напрями управлінських рішень у сфері роздрібної торгівлі, напрями розвитку та використання інноваційних інструментів каналів збуту щодо адаптащії до роздрібних мереж. Як результат, сформовано основні напрями маркетингової збутової стратегії у сфері роздрібної торгівлі, проаналізовано основні напрями управлінських рішень в иій сфері, визначено місие збутової стратегії як функиіональної складової у загальній системі стратегій розвитку торгових мереж, представлено основні напрями розвитку стратегій збуту в конкретних сферах. Обгрунтовано доцільність омніканального підходу, впровадження нових інструментів та технологій у процес збуту, запропонована подальша адаптація й використання інновачійно-технологічного інструментарію до каналів збуту.

Ключові слова: стратегічні напрями, маркетингова стратегія збуту, стратегічне управління, торгівля, роздрібна торгівля, шлях споживача.

Background. In the conditions of impulse development of economy of Ukraine, the strengthened interaction of participants and components of the market, growth of activity in the Internet and constant change of consumer preferences, the key question of extensive development of domestic enterprises of trade is butt.

Today, having the opportunity to travel and receive information about other experiences, consumers make high demands on Ukrainian brands, encouraging them to change and improve, find ways to demanding consumers, strengthen and occupy new positions, expand sales channels using innovative tools to promote products and open interaction at all levels.

Analysis of recent research and publications. The work of many domestic and foreign scientists is devoted to the study of sales activities of trade networks and development strategies, a significant contribution to the theory 
belongs to I. Ansoff, Alfred D Chandler, P. Doyle, K. Hatten. T. Kvasha, A. Mazaraki [1-6], and others.

However, the process of selection and management decisions on effective measures to implement an effective marketing strategy of trade enterprises in a dynamic market economy, the impact on these decisions of global trends remain insufficiently studied and relevant today.

The aim of our research: to analyze the main aspects of the formation of marketing sales strategy, to present management decisions in the field of retail trade, to identify the main directions of development and use of innovative tools of sales channels for adaptation to retail networks.

Materials and methods. The results of research are global trends in marketing strategies, used statistical data, general and special methods of observation, methods of generalization, comparative analysis, structural analysis and systematization of data.

Results. Today, in conditions of intense and dynamic competition, Ukrainian retail chains are successfully copying international experience, expanding the scope and impact on the consumer audience, in Ukraine there are almost 500 retail chains, of which $83 \%$ belong to international companies [7]. Analysis of the state of domestic and foreign trade networks provides prerequisites for predicting the emergence of new, standard formats of trade, an intensive change in relations between sellers and consumers. Over the past 10 years, there has been a change in the factor determinants of the development of trade networks: geographical factor, zoning, change in the range, sales channels, the selection of key strategic management positions. In general, the place of sales strategy as a functional auxiliary in the system of strategies of the trading network is presented in Figure 1.
That is why understanding the causes and consequences of certain management decisions to expand or reduce the network of stores, planning, formation, selection and implementation of marketing strategies, identifying ways to overcome crises - are important for market analysis of Ukrainian retail chains [8].

As we can see, in the scheme of strategic planning in the part concerning competitiveness, the place of the trade enterprise is determined by establishing a connection of any trade enterprise with its environment, implementation of selected strategies and goals in efforts to achieve desired state of relations with the environment through management resource allocation.

V. Sharko emphasizes the main stages of formation of strategic sales management in the field of retail: collection, processing and analysis of information on the state of the internal and external environment, analysis of competitors' strategies; analysis of the influence of factor determinants on the formation of strategies in a particular area; evaluation, formation and development of directions of formation of sales strategies, evaluation and control [11].

Thus, today, according to the analytical data of the Euromonitor.com service, global consumer spending shows a progressive growth in the product sector, the least in the "fashion and beauty" sector.

This figure is quite high in Ukraine, compared to world figures due to the growth of purchasing power of the population, where food (especially water) is still the largest share in consumer spending of Ukrainian households (Figure 2).

At this stage, retail chains do not risk investing in the introduction of new technologies, as required by global consumer trends, giving preference to existing business models. Ukrainian retail chains are actively introducing

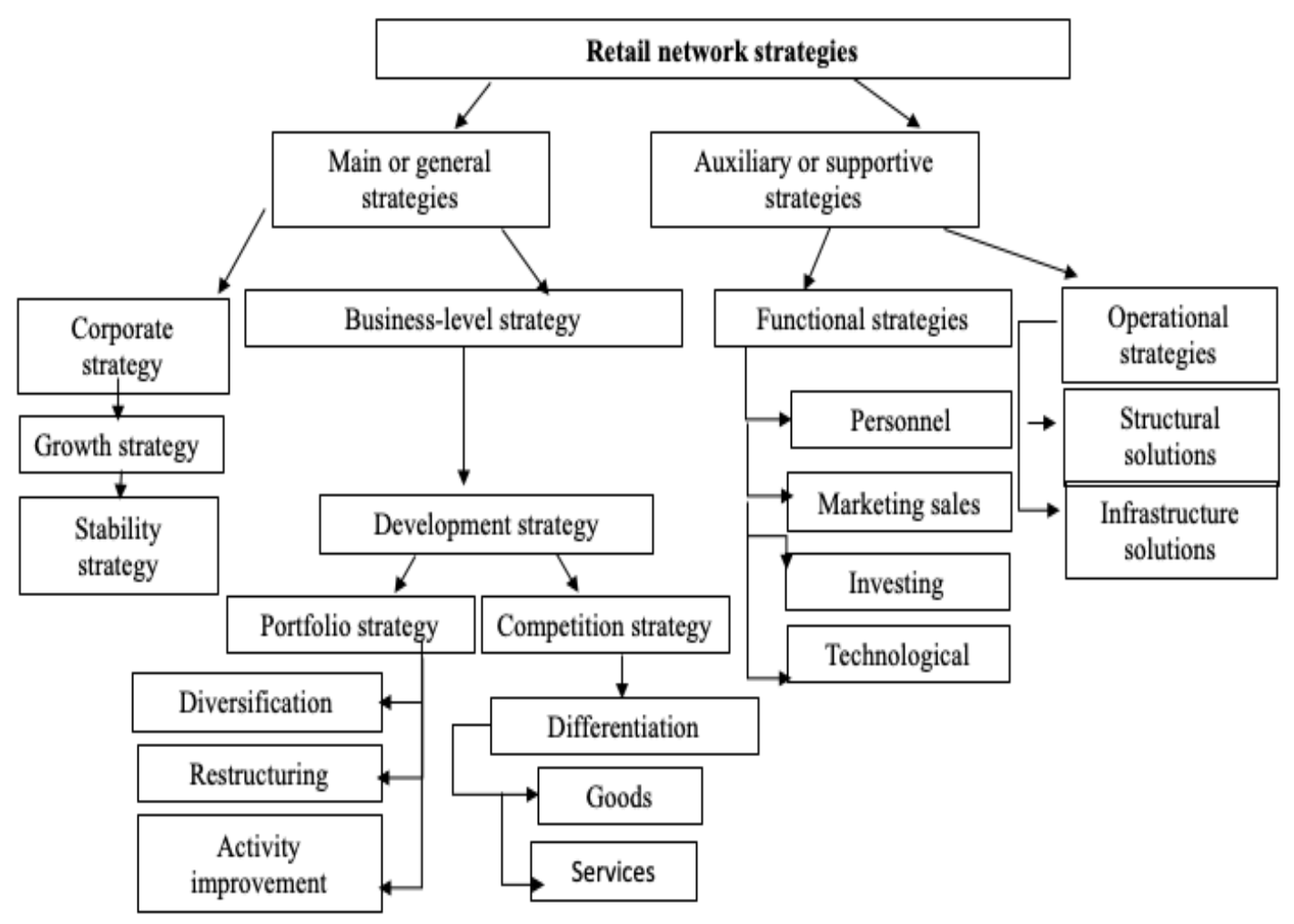

Figure 1. Strategic directions of development of trade networks

Source: developed by authors based on [9; 10] 


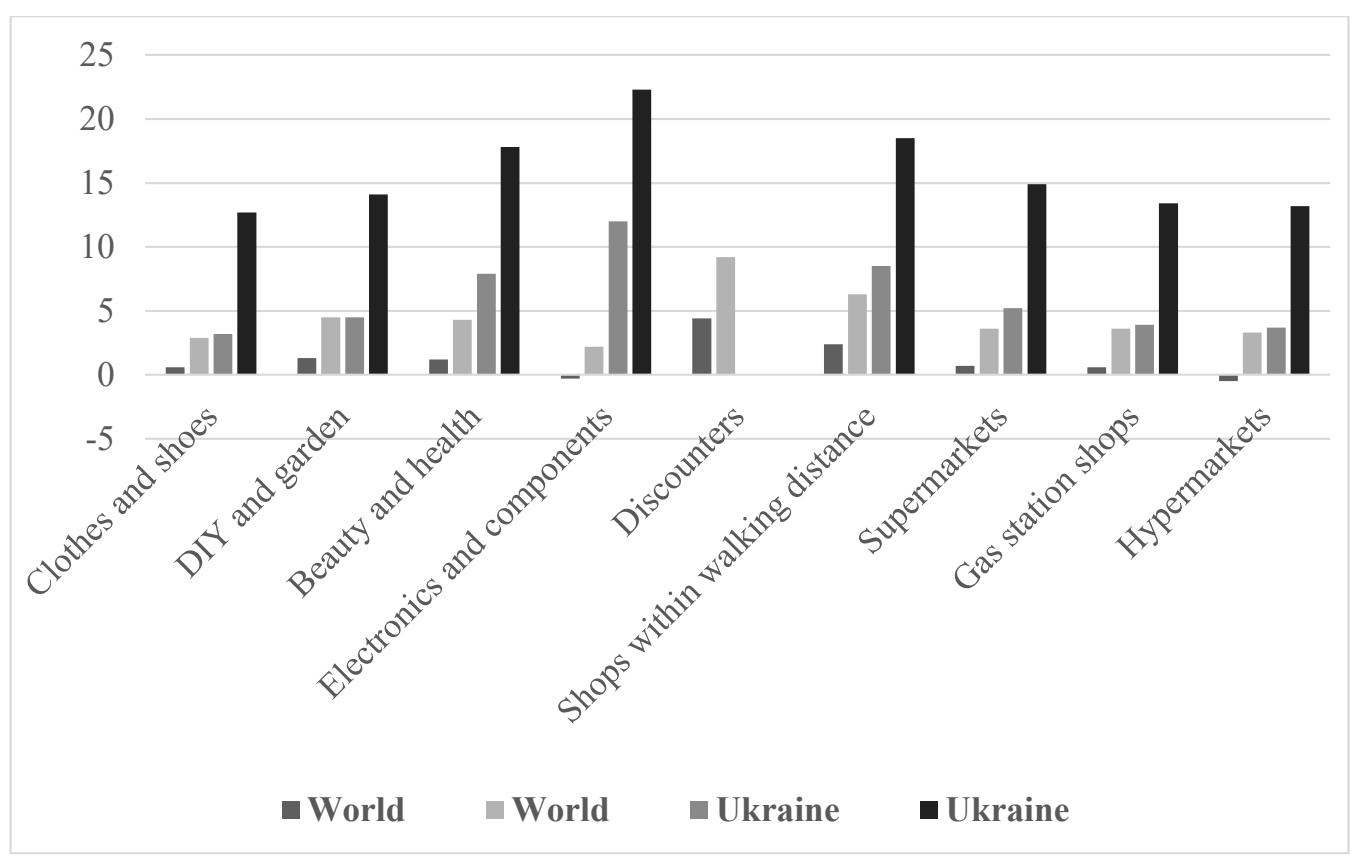

Figure 2. Indices of growth of retail sales of retail chains in Ukraine and the world (2017-2018), \%, according to Euromonitor.com [12]

additional sales of products from other segments, including unexpected related products and services, after the success of Epicenter K, bookstores are testing the sale of diapers, grocery retailers are increasing the range of non-food products, Health Food Store and Combination of Food \& Drug Store offer water sugar-free and fortified refreshing drinks with medicines, the fight for the consumer is conducted in all sales channels, in turn, mineral water brand "Kraina" has developed a partnership program for fitness clubs, including delivery, branding of the club, building a system for selling water to obtain a stable financial result, increasing loyalty to the fitness center [13].

Today, the management of Ukrainian retail chains understands that customer orientation is a strategic basis for brand differentiation, competitive advantage, which is based on monitoring, continuous analysis, study and systematization of global consumer trends, compliance with the established mission and brand ideas. There are a large number of tools for choosing the level of consumer trend implementation, starting from the well-known STS matrix, consumer trend canvas - a template of consumer trend, which allows a comprehensive assessment of a consumer trend, impact and economic effect of its implementation [14].

Thus, against the background of high rates of sales growth, structural changes are taking place, the share of unorganized stores is decreasing, small chains of stores located within walking distance with a wide range of goods, developing networks of discounters and hypermarkets, expanding the representation of foreign retail chains. E-commerce continues to develop rapidly in the world and in Ukraine. More than 22 million Ukrainians are Internet users, of which $31 \%$ made online purchases in 2018 [15]. Most retail chains in Ukraine are present on the Internet, so retailers, in order to differentiate, following the global consumer trend, offer consumers more convenience. According to the latest research of US consumers, compared to 2012, the waiting time for delivery has decreased. If in
2012 consumers agree to wait about 5.5 days, in 2018 this figure is 4.5 days [16]. Given that delivery to Ukraine of purchases from abroad can take 3-4 weeks, therefore, the time indicator is still not critical for the decision to make a purchase from a Ukrainian consumer, but within the country preference is given to those brands that can sell as soon as possible delivery. New companies in the Ukrainian market take this trend into account, for example, the ICOS brand delivers orders between 15 minutes and 3 hours. Some restaurants declare that if the courier does not deliver the order by a certain time, the consumer does not pay for delivery.

The change in the model of consumer behavior, the shift of focus from the product to the consumer experience, provoked the corresponding changes in the format of sales of retail chains [17]. Retail of the last century and the era of the beginning of e-commerce was focused on the product sold, but consumers are increasingly seeking a unique experience of interacting with the brand. Therefore, the latest sales formats - through mobile applications, with the possibility of virtual fitting and other available to consumers elements of the purchase have become a lever of competitive advantage. Virtual reality, augmented reality, the Internet of Things and mobile technologies are changing the consumer experience of Ukrainians and increasing the desire to use the latest technologies and trade formats (Figure 3).

As you can see from the chart and analytical data of Global Entertainment \& Media Outlook, the greatest emphasis today is on the mobile Internet and OOT video. Despite the reduction in the number of offline stores, they still play a key role in the sales process. E-commerce opens up other formats, but to a large extent it is also physical points of sale where consumer services are provided with related services or additional sales, even if it is an online ordering point. Consumers reduce the time to visit the physical store, and seek the experience of interacting with the brand. 


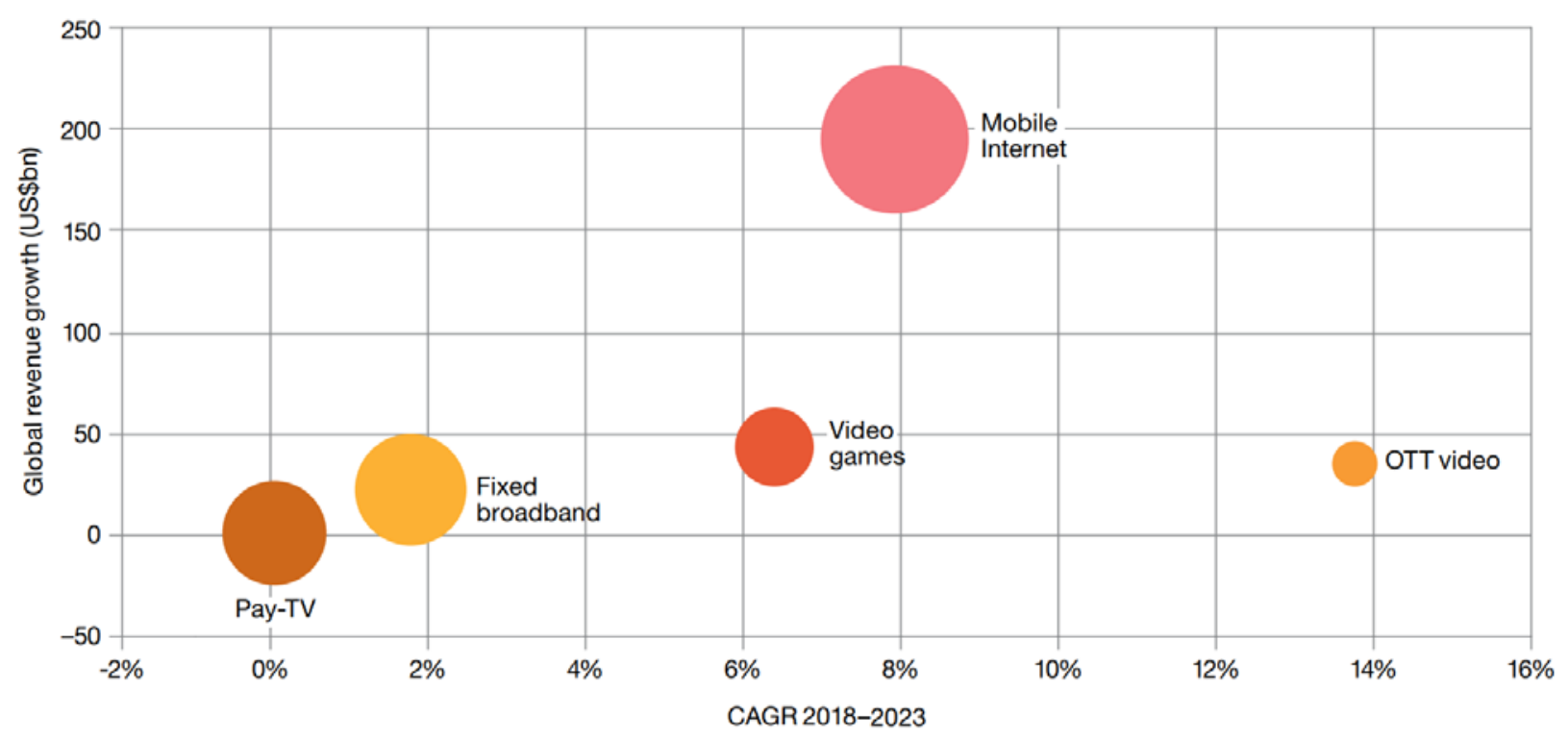

Figure 3. Pools of growth in TMT of the Source:

PwC Global Entertainment \& Media Outlook 2019-2023, www.pwc.com/outlook [18]

Omnichannel helps to make the buying process more convenient and combines e-commerce with offline stores, making it possible to access a single range of products in the retail network, regardless of channel and sales format [19]. A striking example is the international companies VOSS (updated website, VR technology, close customer relationship, personal approach and customization) [20], Evian, Perrier and the Ukrainian brand Morshinska (speed of online registration and delivery directly by the brand, feedback, feedback and brand community in the Internet environment) [21]. Yes, Nestle also sells water through its own Ready Refresh delivery service. In IDS Borjomi Ukraine to ensure uninterrupted supply of quality product all couriers work directly HOD through the delivery service https://mywatershop.ua/, the international company DIY-retailers Leroy Merlin has a chain of stores, online store, contact center, active in social networks, offers consumers services from partners and supports Viber communication channels and e-mail through a collected database of e-mail and telephone [23].

Social networks as an additional channel in sales strategy are often seen as a personal space, and potential customers may not evaluate the commercial offer through those channels. However, if there is a connection to the personal profiles of the consumer, a smart strategy - to interact with their posts with the support of likes / comments / retweets, the brand performs its tasks to confirm the presence of the client. Additionally, the Youtube channel as a sales channel and the Instagram social network, due to the peculiarities of communication and some problems of linking data to CRM, is not used by retail chains at full capacity, while for small businesses it is an effective sales tool.

Facebook is an image resource that allows consumers to express their opinion about the brand or leave feedback.

The author's study showed that retail chains do not take full advantage of social networks, consumer feedback may go unanswered, complaints without a solution, which even leads to lawsuits, proved that the use of omnichannel approach in strategic sales management, gives conversion rate to potential customers. $28 \%$ higher than representatives using other strategies (Table 1).

The following matrix provides a visual overview of how the sales channel (for example, e-mail) should be used for potential retail consumers who have already received an offer and are in the process of making a purchase decision.

In the system of strategic sales management, the development of omnichannel requires discipline and determination. Sales teams can also consider automated workflows to help them perform multi-channel follow-up without losing all the different platforms and their respective nuances.

Conclusions. Thus, the state of development of retail trade networks in Ukraine indicates important social and

An omnichannel approach for retailers

(example based on email channel) [24]

\begin{tabular}{|c|c|c|c|c|c|}
\hline & Base collect & Primary touchpoint & $\begin{array}{l}\text { Secondary } \\
\text { touchpoint }\end{array}$ & Remainder & $\begin{array}{c}\text { Social Followup } \\
\text { Touchpoint }\end{array}$ \\
\hline \multirow[t]{2}{*}{ Channels } & Different sources & E-mail & Messenger & SMS & $\begin{array}{l}\text { Remarketing, Facebook, } \\
\text { Instagram }\end{array}$ \\
\hline & Base collect & Primary touchpoint & $\begin{array}{l}\text { Secondary } \\
\text { touchpoint }\end{array}$ & Remainder & $\begin{array}{c}\text { Social Followup } \\
\text { Touchpoint }\end{array}$ \\
\hline Purpose & CRM pack & $\begin{array}{c}\text { Engage or re-engage } \\
\text { with content relevant to } \\
\text { requested merchandise, } \\
\text { call-to-action }\end{array}$ & $\begin{array}{l}\text { Follow-up, } \\
\text { updates and } \\
\text { recommendations }\end{array}$ & $\begin{array}{c}\text { Brief to the point } \\
\text { ask }\end{array}$ & $\begin{array}{l}\text { Engage with the social } \\
\text { life of the retailer to } \\
\text { trigger to buy more from } \\
\text { the same chane }\end{array}$ \\
\hline
\end{tabular}


economic processes within the state and regions, reflects the dynamics of changes in living standards. In general, to make optimal management decisions in strategic sales management, you need to understand consumer preferences, decision-making preferences, monitor their moods and analyze the purchasing process, which necessitates further research on consumer preferences when interacting with retail chains.

It is important to monitor these processes with an omnic approach, using the latest technologies and sales channels, using ATL / BTL-activity with promotion in digital channels, development and inclusion of social networks and messengers, effective tools for research and analysis of consumer sentiment, increasing loyalty consumer audience to the brand in Ukraine.

Prospects for further development are a more detailed analysis of trends in the development of retail chains, development and adaptation of marketing strategies for different markets, taking into account the specifics of retail chains.

\section{References:}

1. Ansoff I. (1989) Strategycheskoe upravlenye [Strategic management]. Moscow: Economica. (in Russian)

2. Chandler Alfred D. (1962/1998) Strategy and Structure: Chapters in the History of the American Industrial Enterprise. Cambridge, MA: MIT Press, $463 \mathrm{p}$.

3. Doyle P. (2001) Shareholder-value-based strategies. Brand Management, Henry Stewart Publications 1350-231 X, 2001, Vol. 9, No. 1.

4. Hatten K.J., Hatten M.L. (1988) Effective Strategic Management, Englewood Cliffs, NJ: Prentice-Hall.

5. Johnson G. (2007) Exploring Corporate Strategy: text and cases, $5^{\text {th }}$ ed. Financial Times: Prentice Hall, $664 \mathrm{p}$.

6. Mazaraki A.A., Bosovska M.V. (2013) Teoretychni ta metodologichni zasady formuvannya integraciynoï strategiï pidpryyemstv [Theoretical and methodological bases of enterprises’ integrated strategy formation]. Biznes Inform, № 7, pp. 299 -308.

7. Stan innovacijnoyi diyalnosti ta diyalnosti u sferi transferu texnologij v Ukrayini u 2018 roci: analitychna dovidka [The state of innovation and technology transfer activities in Ukraine in 2018: analytical data]. T.V. Pysarenko, T.K. Kvasha and others. Kyiv: UkrINTEI, $80 \mathrm{p}$.

8. Derzhavna sluzhba statystyky Ukrainy [State Statistics Service of Ukraine] (electronic source). Available at: http://ukrstat.gov.ua/ (accessed at: 13 August 2020).

9. Lahotska N.Z. (2014) Utochnennia zmistu ta aktualni pryntsypy zbutovoi polityky pidpryiemstva [Content clarification and current principles of sales policy of the enterprise]. Biznes Inform, № 5, pp. 302-306.

10. Tymofeieva O.V. (2007) Rozvytok ukrainskykh torhovelnykh merezh na suchasnomu etapi [Development of Ukrainian trade chains at the present stage]. [Economy and region]. Economy and region, № 2(13), pp. 68-72.

11. Sharko V.V. (2018) Formuvannia systemy stratehichnoho upravlinnia konkurentospromozhnosti pidpryiemstva [Formation of a system of strategic management of enterprise competitiveness]. Available at: http:/www.market-infr.od.ua/journals/2018/20_2018_ ukr/27.pdf (accessed at: 13 August 2020).

12. Understanding The Impact Of Coronavirus (COVID-19). Available at: https://www.euromonitor.com/ (accessed at: 13 August 2020).

13. Mineralna voda TM Kraina dlia fitnes-tsentriv [Mineral water of TM Kraina for fitness centers]. Available at: https://rademaster.ua/news/22382 (accessed at: 13 August 2020).

14. Consumer trends canvas. Available at: https://trendwatching.com/trends/consumertrendcanvas/ (accessed at: 10 January 2020).

$15.17 \%$ ukrainskykh onlain-pokuptsiv zdiisniuiut bilshe 20 pokupok na rik [17\% of Ukrainian online shoppers make more than 20 purchases a year]. Available at: https:/www.gfk.com/uk-ua/rishennja/news/online-shopping-2019 (accessed at: 29 August 2019).

16. Jim Blaeser, Marc Iampieri and Roshan Varma (2018) Top trend in shipping? More consumers want fast and free. AlixPartners survey. Available at: https://emarketing.alixpartners.com/rs/emsimages/2018/pubs/EI/AP_Top_Trend_in_Shipping_Mar_2018.pdf (accessed at: 29 September 2019).

17. Goloshubova N.O. (red.) (2014) Business networks in trade [Business networks in trade]. KNUTE, $316 \mathrm{p}$.

18. PwC Global Entertainment \& Media Outlook 2019-2023. Available at: www.pwc.com/outlook (accessed at: 29 September 2019).

19. Romanchenko T.V. (2018) Limitations of omnichannel [Omnichannel limitations]. № 9. Efektyvna ekonomika [Efficient economy]. Available at: http://www.economy.nayka.com.ua/?op=1\&z=6545 (accessed at: 29 August 2019).

20. Derii Zh.V., Zavhorodnia N.V. (2016). Stratehichnyi napriam innovatsiinoho rozvytku kharchovoi promyslovosti [Strategic direction of innovative development of the food industry]. Ukraine - EU. Modern technology, business and law: collection of international scientific papers: in 2 parts. Part 1. Modern priorities of economics. Engineering and Tehnologies. Chernihiv: CNUT, pp. 117-122.

21. Official website of TM Morshinska. Available at: https://www.morshynska.ua/ (accessed at: 29 August 2019).

22. Full-Year Results 2018. Available at: https://www.nestle.com/media/pressreleases/allpressreleases/full-year-results-2018 (accessed at: 29 August 2019).

23. Official website of TM Leroymerlin. Available at: https://www.leroymerlin.com/ (accessed at: 29 August 2019).

24. Omnichannel-sales-strategy. Available at: https://about.crunchbase.com/blog/omnichannel-sales-strategy (accessed at: 29 August 2020). 